\title{
From the defective to the effective: exploiting fortuitous errors in non-native speakers' written productions
}

Ray Cooke and Susan Birch-Bécaas

\section{(2) OpenEdition \\ Journals}

Electronic version

URL: http://journals.openedition.org/asp/2604

DOI: $10.4000 /$ asp.2604

ISBN: 978-2-8218-0380-0

ISSN: 2108-6354

\section{Publisher}

Groupe d'étude et de recherche en anglais de spécialité

\section{Printed version}

Date of publication: 1 December 1999

Number of pages: $375-388$

ISSN: 1246-8185

Electronic reference

Ray Cooke and Susan Birch-Bécaas, «From the defective to the effective: exploiting fortuitous errors in non-native speakers' written productions", ASp [Online], 23-26 | 1999, Online since 07 January 2011 connection on 02 May 2019. URL : http://journals.openedition.org/asp/2604 ; DOI : 10.4000/asp.2604

This text was automatically generated on 2 May 2019.

Tous droits réservés 


\title{
From the defective to the effective: exploiting fortuitous errors in non- native speakers' written productions
}

\author{
Ray Cooke and Susan Birch-Bécaas
}

1 When writing research papers, non-native speaker (NNS) students and researchers must meet the requirements of their discourse community. Swales' deconstruction of the research article (RA) into its constitutive "moves" has proved an invaluable basis for many academic writing courses. Authentic RAs can be didacticised according to the needs of students, focusing on both text structure and language elements. Indeed, it is hoped that the examination of model articles will lead NNS students to identify rhetorical functions and then imitate the organisational framework in their own writing, helping them to avoid any cultural interferences in the overall structure of the paper. On another level, NNS students need to achieve a degree of accuracy in their writing before submitting it for publication. Getting students to work collaboratively on editing errors draws their attention to certain language points which may be problematic. The aim of this paper is to outline an approach taken in designing and teaching a writing course for French doctoral students, based partially on the written productions of French-speaking (FS) researchers. FS researchers' drafts may create interesting input for their peers, enabling them to see if the model "moves" have been reproduced on a global, organisational level and to work on the correctness of the text on a more local languagebased level.

2 The public we are dealing with are first-, second- and third-year PhD students in the fields of biological and medical science. By reading articles in their field they have gained some knowledge of organisational patterns. At text-level, this knowledge can be reinforced by asking students to pinpoint moves or reorder elements to work on text cohesion in model texts or as in this case FS drafts. However, Dudley-Evans (1995a) warns against being over-prescriptive. Indeed the typical text structure may vary across the 
disciplines, but this fact may be used to compare and contrast organisational schemata as we will see later, enriching peer feedback. The moves then need to be linked to the linguistic elements which are typically used to make the move. For example, form and function can be linked by matching sentences lifted from the article with the appropriate section of the article (Hill et al. 1982). The textbooks of Swales and Feak (1994) and Weissberg and Buker (1990) associate the rhetorical moves with their linguistic realisations. Weissberg and Buker illustrate, for example, how choice of tense may translate the author's attitude towards findings in a review of the literature. Study of authentic texts and those produced by peers will thus enable students to move from identifying the function of a sentence to studying how the author's linguistic choices interpret that function. In this way, the student will be sensitised to tense usage, typical syntactic features, lexical phrases and link words which may be used to signal moves. Nattinger and DeCarrico advocate training students to

identify and use top-level organizational structures along with appropriate signalling devices. Mapping and hierarchical outlining of high-level discourse movement in terms of interlacing lexical phrases would increase students' awareness of information flow. (1992: 163)

In our course, the efficacy of an FS production is put to the test by peer review. DudleyEvans (1995b) advocates this practice in his writing club "to focus on the needs of the reader trying to grasp the meaning of the text".

Peer review may also be used on the sentence-level to edit errors which could distract the reader. As Master points out, in a study on the use of the article,

In this setting (academic) attention to the article is particularly important, as local errors such as articles, prepositions and subject-verb agreement, even though they do not affect understanding can have a negative effect on the reader, especially non-ESL faculty, as they have the impression that the writer has inadequate control of the language. (1995: 184)

$5 \quad$ FS drafts can be revised and reformulated allowing the students to formulate hypotheses which are then exploited by the teacher. Robb, Ross and Shortreed (1986) have found evidence against direct correction of surface errors in written work and advocate problem-solving activities and indirect feedback, asking students to locate errors and make revisions or reconstruct the text.

\section{Introduction sections written by French-speaking researchers}

We will now focus on the introduction sections written by FS researchers. As we have seen, analysis of the drafts will enable students to identify the moves and compare with genre models (Swales' CARS model, 1990) and Nwogu's moves for medical research papers (1997). The moves also help us to identify characteristic linguistic features of the introduction.

7 Nwogu establishes the following pattern: background information will be presented using present tense verb forms for established knowledge and locative and temporal adverbials to set the scene; the literature review will be realised either in the simple past to refer to one piece of research, the present perfect for a more generalised reference or the present tense to indicate implications for the new research; adversative adverbials and negative forms will signal a gap in past research and finally the present research purpose is given 
in the present simple. We are thus able to envisage the type of problems that FS researchers might have in writing up this section.

Indeed a previous error analysis of 40 such drafts (Birch 1996) has revealed problems that recur in the introduction section for FS researchers. Annex 1 (top) shows the frequency of errors in the introductions compared with the overall results for the corpus. They are classified in global categories or 'families'. We can thus see that in the introduction, the problems of tense are more important than those of determination. As we mentioned above, the author must situate his study in its context, providing the reader with background information, referring to previous research and stating his objectives. Annex 1 (bottom) shows the errors classified in individual categories. The top four categories follow the same pattern as the article taken as a whole: inappropriate lexical choice, prepositions and then use of the zero and definite article. We can see that the introduction sections normally represent about $13 \%$ of the errors of the corpus. However certain types of error are much more present in this part of the article. The FS author does not master the use of the present perfect to refer to previous studies nor the use of the present simple to present general truths. Finally, the use of coordinating conjunctions to link and emphasise relations between ideas may pose problem.

In the next section, we shall take three first drafts (annex 2) produced by fully-fledged FS researchers in our university. While these drafts are defective for a number of reasons, their overall structure fits the CARS model. For example, all three kick off with topic centrality, differ slightly in the way previous results or remaining questions are presented, but end firmly by occupying a niche. Although unable to name the moves they are making, such FS writers are normally interested in them and aware of these conventions through their own personal observation of the research process and by way of peer discussion within their team. Indeed, a first draft as seen by our in-house English language reviewer is frequently the result of much previous debate between colleagues regarding the content, its organisation, and the style of the writing. In this sense, it is not strictly speaking the first draft. On the other hand, such collective thought will go some way to improving the language, but may not make it acceptable in the eyes of the reading committee to which the article might be sent for publication. ${ }^{1}$

10 It is therefore essential to capitalise on this interest in the correctness of scientific English, particularly when working with doctoral students setting out on their careers. If the latter may be made aware of move analysis, on the one hand, and of the interlanguage errors that they may commit, on the other, then they would arguably be given greater control over the way they communicate with their discourse community and the place they may occupy within it. Therefore, language instruction in this area should aim to provide learners with a set of readily accessible tools to which reference may be made when needed. Such tools cannot allow the learner to produce the perfect text, but will allow him to get closer to an acceptable form of expression. What follows is in no way exhaustive but represents a range of activities which meet this need.

11 Spelling mistakes are irritating to the native reader yet almost all first drafts written by non-natives will contain them. However, the advent of spellcheckers has not been accompanied by a collective awareness that they should be used whenever a text is produced. Therefore, it would seem sound practice to encourage our learners to use one at all times. Although the differences in this respect between British and American English are frequently anecdotal, it is worthwhile making sure that the most flagrant ones are known (e.g. tumor, organization), and that learners know how to use the language 
option in the tools menu of a package like Word 7. Many do not. Annex 3 shows what the Word 7 spellchecker picked up in our three drafts. Although the net result is only four errors rectified, the step was a useful one: it improved the text; and it drew the learner's attention to errors (typographical or not) which otherwise would have gone unnoticed. Thereafter, learners would do well to note down such errors committed/corrected in structured note-taking like that referred to by several authors, including one of us (Cooke 1995).

Note, however, that the error "DNA stand cleavage" (annex 3, introduction 2) is obviously not picked up by the spellchecker. So who/what should pick it up? Now, no reader of the present article should feel at a loss if they cannot see where the error is here, because it is very likely that a group of learners at doctoral level would themselves find it. To feel comfortable here, it is important for the ESP teacher to know how to set up the heuristic learning environment for that learner interaction to take place. ${ }^{2}$ On the other hand, it is essential for teachers to learn special English in an ongoing manner; perhaps they too should also make personal notes in the same way as their learners. In this way, the above error ("stand" for "strand" = un brin) would be identifiable.

\section{Multi-faceted approach}

13 It is this continuously progressing knowledge of special English which makes possible what follows. To exploit the learners' knowledge further, we as teachers need to draw their attention to ways of improving first drafts without excessive intervention on our part. Technical writing classes/workshops are now widely described in the literature but still seem few and far between in France. Perhaps one of the obstacles is the multidisciplinary nature of the participants, since no institution will ever have enough doctoral students sensitised to the need to work in such a way and all available at the same time in the week to customise such a course for any one discipline. Yet would a course like that be as desirable as the multi-disciplinary workshop, where attention may be drawn not only to various written genres but also to the fact that not all disciplines use the same genres to the same extent, and that the use of moves and even language structures may show considerable trans-disciplinary variation? ${ }^{3}$ Even tenets such as "read the title, then the abstract, introduction and conclusion" are open to challenge: e.g., epidemiologists frequently go straight to the Methods and Materials section; if the method does not look watertight mathematically and statistically, the article will immediately be treated with circumspection, irrespective of any claims it may make. Therefore, on the contrary, the participants of a multi-disciplinary workshop have much to offer each other.

We must therefore find a multi-faceted approach combining stylistic, organisational, grammatical and lexical interest for all concerned.

One way to arouse interest is by highlighting (but not correcting) problems/errors in first drafts. Edge (1989) has produced a simple problem-highlighting code for learners which we have complemented (annex 4). When applied to our intro. 2, the profile in annex 5 is obtained. These profiles may be used for group discussion, pair work, etc. with a view to improving them. Remember what a reasonable aim is here:

L'objectif pour un étranger qui rédige en anglais n'est donc pas de produire un texte qu'on puisse croire rédigé par un anglophone mais de produire un texte dont 
l'organisation est assez conforme au modèle anglo-saxon pour que le comité de lecture le juge acceptable. (Régent 1980). acquire a model or models of the various sections of the academic text. There is at present considerable interest in the way models are acquired. Their value is accepted now, even though some results are mitigated. In a four-month study of the peer-editing behaviour of undergraduate students in a third-year Spanish composition and grammar review course, Amores (1997) found the process not to be as effective as expected. However, several socio-cultural variables could have influenced the outcome in that study. In the setting of Japanese graduates drafting their first research papers, Gosden (1998) used a modelling device termed "propositional clustering" to help his writers control thematic development. The procedure proved very valuable. In any respect, it is clear that academic writing is facilitated at almost all levels by collaborative effort aiming to gain admission to the discourse community. Since syntactic and organisational models are conventions of such communities, it seems illogical not to try to imitate them. The point with our FS-learners is that by examining and imitating the English expression of their seniors who have already "made the grade", they are thus able to develop their own model which is different from the native speaker/writer model but is as acceptable. In this, the quest for forms of expression particular to this group appears valid.

Finally, it is interesting to cast a glance at the outcome of the first drafts: the published version. Annex 8 shows one such introduction. The final version looks little like the first. However, it should be remembered that before being published, a paper undergoes considerable to-ing and fro-ing between research team and journal in order to improve it. During this process, additions and deletions will be made, afterthoughts will be added, and the editor's suggestions will frequently be taken into account. Obviously, this is the case here. What is important, though, is the fact that the article was accepted if revisions were made. Arguably this would not have been so if the level of English expression had not initially been adequate. In other words, the "foot in the door" was probably gained in this way, sufficiently for a fair amount of editing to be assumed by the journal itself. In other words, the scientific content was considered interesting and comprehensible enough to be given a final helping hand on board.

In conclusion, if we as teachers can set up the conditions for young researchers to acquire a working knowledge of what is involved in publishing in English (and the exercises here mentioned are only one part of that process), then we will be offering them the sort of help many of their predecessors never received. 


\section{BIBLIOGRAPHY}

Amores, M. J. 1997. “A new perspective on peer-editing”. Foreign Language Annals 30/4, 513-522.

Birch, Susan. 1996. "Les besoins linguistiques des scientifiques français publiant en anglais :

Analyse d'un corpus de premières rédactions et de leur correction". Thèse de doctorat de l'Université de Bordeaux 2.

Cooke, Ray. 1995. "High level discourse and low level learners: An unlikely marriage". ASp 7-10, 217-230.

Dudley-Evans, T. 1995a. "Genre models for the teaching of academic writing to second language speakers: Advantages and disadvantages". TESOL Journal France 2/2, Functional Approaches to Written Text: Classroom Applications.

Dudley-Evans, T. 1995b. "Common-core and specific approaches to the teaching of academic writing". In Belcher \& Braine (eds.), Academic Writing in a Second Language: Essays on Research and Pedagogy. Norwood, NJ: Ablex.

Edge, Julian. 1989. Mistakes and Correction. New York: Longman.

Gosden, H. 1995. "Success in RA writing and revision: A social-constructionist perspective”. ESP 14/1, 37-57.

Gosden, H. 1998. “An aspect of holistic modelling in academic writing: propositional clusters as a heuristic for thematic control". Journal of Second Language Writing 7/1, 19-41.

Hill, S., Soppelsa, B. \& G. West. 1982. "Teaching ESL students to read and write experimental research papers". TESOL Quarterly 16/3, 333-346.

Johns, A. 1995. "Teaching classroom and authentic genres: Initiating students into academic cultures and discourses". In Belcher \& Braine (eds.), Academic Writing in a Second Language: Essays on Research and Pedagogy. Norwood, NJ: Ablex.

Master, P. 1995. “Consciousness raising and article pedagogy”. In Belcher \& Braine (eds.), Academic Writing in a Second Language: Essays on Research and Pedagogy. Norwood, NJ: Ablex.

Nattinger, James R. \& Jeanette S. DeCarrico. 1992. Lexical Phrases and Language Teaching. Oxford: Oxford University Press.

Nwogu, K. 1997. “The medical research paper: Structure and functions”. ESP 16/2, 119-138.

Perrin, M. 1992. "De l'utilisation communicative des documents authentiques". In Perrin, M. (ed.), Du linguistique au didactique, Actes du 11e Colloque 1990 du GERAS, Bordeaux, 11-33.

Régent, O. 1980. "Le discours médical écrit en français et en anglais. Étude comparative en vue d'applications pédagogiques". Thèse de doctorat, Université de Nancy.

Robb, T., Ross, S. \& I. Shortreed. 1996. Salience of feedback on error and its effect on ESL writing quality". TESOL Quarterly 20/1.

Swales, J. \& C. Feak. 1994. Academic Writing for Graduate Students: Essential tasks and skills. Michigan: University of Michigan Press. 
Swales, J. 1990. Genre Analysis: English in Academic and Research settings. Cambridge: Cambridge University Press.

Weissberg, R. \& S. Buker. 1990. Writing Up Research. Experimental Research Report Writing for Students of English. Englewood Cliffs, NJ: Prentice Hall Regents.

\section{NOTES}

1. It may even be prejudicial to the quality of the language, an observation particularly true in the case of multicentric studies in which any number of the co-authors may decide to modify for the worse a sentence hitherto correctly formulated.

2. For a discussion of this, see Perrin 1990.

3. For example, see Swales 1990: 161.

\section{ABSTRACTS}

An approach is described in which the written errors of fully-fledged French-speaking researchers are exploited for the benefit of their doctoral students. Moreover, it is postulated that the written discourse of the former may even serve as a model for the latter.

Les auteurs décrivent une approche dans laquelle certaines erreurs écrites commises par des chercheurs francophones confirmés sont exploitées dans un programme de rédaction scientifique destiné aux doctorants francophones. De plus, ils avancent que le discours écrit des uns peut même servir de modèle pour celui des autres.

\section{INDEX}

Mots-clés: approche didactique, chercheur (francophone confirmé), doctorant, erreur (fortuite) Keywords: didactic approach, doctoral student, error (fortuitous), researcher (French-speaking full-fledged)

\section{AUTHORS}

\section{RAY COOKE}

Ray Cooke est maître de conférences au DLVP-CRIFEL, Université Victor Segalen Bordeaux 2. Il s'intéresse particulièrement à la didactique de l'anglais de spécialité. ray.cooke@lv.ubordeaux2.fr

\section{SUSAN BIRCH-BÉCAAS}

Susan Birch-Bécaas est maître de conférences au DLVP-CRIFEL, Université Victor Segalen Bordeaux 2 où elle enseigne principalement dans les filières d'odontologie et de médecine. Sa recherche est axée sur l'analyse du discours scientifique. susan.birch@lv.u-bordeaux2.fr 